SHEs: Conference Series 3 (4) (2020) $902-906$

\title{
Efforts to Increase Students' Learning Achievement On Fraction Materials in Class V Semester 1 Through The Application Of The Make a Match Learning Model In Sd Negeri Dawuhan 03 Academic Year 2019/2020
}

\author{
Novi Aryanti
}

SD Negeri Dawuhan 03

novia3748@gmail.com

\section{Article History}

received $3 / 12 / 2020$

revised $17 / 12 / 2020$

accepted 31/12/2020

\begin{abstract}
The research objective to be achieved is to improve student learning achievement in fractional material in class V SD Negeri Dawuhan 03, Sirampog District, Brebes Regency for the 2019/2020 academic year through the Make a match learning model. This form of research uses Classroom Action Research. The research subjects used were the fifth grade students of Dawuhan 03 State Elementary School, Sirampog District, Brebes Regency for the 2019/2020 academic year as many as 37 students. The results of the study can be seen that the percentage of student learning completeness in cycle 1 of 37 students there are $26(81.08 \%)$ students who complete and the rest 11 (29.72\%) students have not obtained completeness, with an average value of 79,02 . In cycle 2 of 37 students there were $35(94.59 \%)$ students who completed and the remaining 2 (5.40\%) students had not obtained completeness with an average value of 90.32. Based on the available information, it can be concluded that the use of the make a match learning model can improve student learning achievement on fraction material in class V SD Negeri Dawuhan 03.
\end{abstract}

Keywords: learning achievement, fractions, make a match

\begin{abstract}
Abstrak
Tujuan penelitian yang akan dicapai adalah untuk meningkatkan prestasi belajar peserta didik pada materi pecahan di kelas V SD Negeri Dawuhan 03, Kecamatan Sirampog, Kabupaten Brebes tahun pelajaran 2019/2020 melalui model pembelajaran Make a match. Bentuk penelitian ini menggunakan Penelitian Tindakan Kelas. Subjek penelitian yang digunakan adalah peserta didik kelas V SD Negeri Dawuhan 03, Kecamatan Sirampog, Kabupaten Brebes tahun pelajaran 2019/2020 sebanyak 37 peserta didik. Hasil penelitian dapat diketahui bahwa presentase ketuntasan belajar Peserta didik pada siklus 1 dari 37 Peserta didik terdapat 26 $(81,08 \%)$ peserta didik yang tuntas dan selebihnya $11(29,72 \%)$ peserta didik belum memperoleh ketuntasan, dengan rata-rata nilai 79,02. Pada siklus 2 dari 37 Peserta didik terdapat $35(94,59 \%)$ peserta didik yang tuntas dan selebihnya $2(5,40 \%)$ peserta didik belum memperoleh ketuntasan dengan rata-rata nilai 90,32. Berdasarkan keterangan yang ada maka dapat disimpulkan bahwa penggunaan model pembelajaran make a match dapat meningkatkan prestasi belajar Peserta didik pada materi pecahan di kelas V SD Negeri Dawuhan 03.
\end{abstract}

Kata kunci: Prestasi belajar,Pecahan,Make A Match

Social, Humanities, and Education Studies (SHEs): Conference Series p-ISSN 2620-9284 https://jurnal.uns.ac.id/shes e-ISSN 2620-9292 


\section{PENDAHULUAN}

Prestasi belajar merupakan hal yang paling penting dalam pembelajaran.Menurut Sudjana (2003:9), "Prestasi belajar pada hakikatya adalah perubahan tingkah laku sebagai hasil belajar, dalam pengertian yang lebih luas mencangkup bidang, kognitif,efektif,dan psikomotorik". Menurut Muhibbin Syah (2011: 68) "Belajar adalah tahapan perubahan seluruh tingkah laku individu yang relatif menetap sebagai hasil pengalaman dan interaksi dengan lingkungan yang melibatkan proses kognitif". Sumadi Suryabrata (2006: 297) merumuskan prestasi sebagai berikut: "Prestasi Belajar sebagai nilai yang merupakan bentuk perumusan akhir yang diberikan oleh guru terkait dengan kemajuan Prestasi Belajar peserta didik selama waktu tertentu". Dimyati dan Mudjiono (2006:3-4) juga mendefinisikan "Prestasi belajar merupakan hasil dari suatu interaksi tindak belajar dan tindak mengajar". Dari sisi guru, tindak mengajar diakhiri dengan evaluasi hasil belajar. Dari sisi peserta didik, hasil belajar merupakn berakhirnya pengajaran dari puncak proses belajar. Menurut Rusman (2011:223) dikatakan bahwa model pembelajaran make a match (membuat pasangan) merupakan salah satu jenis dari metode pembelajaran kooperatif. Menurut Anita Lie (2010:55) teknik mengajar mencari pasangan (Make a Match) dikembangkan oleh Lorna Curran (1994). Salah satu keunggulan teknik ini adalah peserta didik mencari pasangan sambil belajar mengenai suatu konsep atau topik dalam suasana yang menyenangkan. Kartu-kartu tersebut terdiri daru kartu yang berisi pertanyaan-pertanyaan dan kartu yang berisi jawabandari pertanyaan tersebut. Model pembelajaran make a match ini dapat membuat suasana belajar jadi menyenangkan dan lebih menarik. Dengan keterlibatan peserta didik dalam kegiatan pemebelajaran maka akan terjalin komunikasi yang baik antara peserta didik dengan peserta didik maupun peserta didik degan guru, sehingga informasi yah disampaikan guru akan mudah dipahami. Kerjasama antara peserta didik yang terjalin pada saat mencari pasangan dan keberanian mengemukakan pendapat pada saat membacakan hasil temuannya dalam mencari pasangan merupaan kelebihan dari model pembelajaran make a match.

Berdasarkan data yang diperoleh dari kelas V SD Negeri Dawuhan 03 semester 1 tahun 2019 hanya 15 peserta didik atau 40,55\% yang telah memenuhi standar ketuntasan minimal dan masih ada 22 peserta didik atau 59,46\% yang belum memmenuhi standar ketuntasan minimal. Selain itu nilia rata-rata kelas masih rendah yaitu sebesar 66,72. Masih banyak peserta didik yang mengalami tidak tuntas belajar karena proses belajar.

Berdasarkan latar belakang di atas, maka diperoleh rumusan masalah sebagai berikut :

1. Bagaimana proses pembelajaran make a match pada materi pecahan dapat meningkatkan aktivitas dan prestasi belajar peserta didik kelas V SD Negeri Dawuhan 03 ?

2. Seberapa besar peningkatan prestasi belajar peserta didik pada materi pecahan setelah penerapan model pembelajaraan make a match pada peserta didik kelas V SD Negeri Dawuhan 03?

Untuk mengatasi permasalahan rendahnya kemampuan peserta didik dalam mata pelajaran matemtika di SD Negeri Dawuhan 03 maka perlu digunakan pembelajaran yang baru dan menyenangkan. Metode pemebelajaran yang dimaksud adalah model pembelajaran make a match ( mencari pasangan) yaitu tipe yang dikembngkan Lorna Curan (1994).

Dari uraian latar belakang dan rumusan masalah di atas Penelitian Tindakan Kelas ini secara umum memiliki tujuan untuk mengatasi masalah yang terjadi pada pembelajaran supaya pembelajaran yang berlangsung mendapatkan hasil yang lebih baik sehingga prestasi belajar peserta didik meningkat.

\section{METODE}

Penelitian ini mneggunakan metode penelitian tindakan kelas (classroom action research). Dalam penelitian tindakan kelas ini, peneliti menggunakan 2 siklus yaitu siklus I dan 
II. Tiap-tiap siklus terdiri dari empat tahap yaitu perencanaan (planning), pelaksanaan (acting), pengamatan (observing), dan refleksi (reflecting). Pengumpulan data yang dugunakan dalam Penelitian Tindakan Kelas ini adalah observasi dan tes tertulis. Instrumen yang digunakan untuk pengumpulan data dalam penilaian tindakan kelas ini berupa instrument test dan nontest, instrumen tes digunakan untuk mengungkapkan data tentang prestasi belajar materi pecahan.

Intrumen nontes berupa lembaran observasi yang digunakan untuk mengungkapkan aktivitas guru dan peserta didik selama kegiatan pembelajaran. Pada tahap ini dilakukan analisis data yag telah dicapai oleh peserta didik melalui tes dan observasi. Hasil analisis data pada siklus I digunakan untuk kegiatan siklus II.Data yang sudah terkumpul dihitung dan dianalisis dengan deskriptif, kualitatif dan kuantitatif. Setiap akhir diadakan tes untuk mengukur kemempuan peserta didik.

Validasi data menggunakan data tes prestasi belajar dan data pengamatan (observasi). Analisis data tes prestasi belajar dengan membandingkan hasil ulangan harian kondsi awal,hasil ulangan formatif sikus I, dan hasil ulangan formatif suklus II. Analissi data pengamatan observasi diperoleh dalam penelitian ini berupa data hasil observasi, kemendirian belajar, hasil tes dan dokumentsi.

\section{Siklus I}

\section{HASIL DAN PEMBAHASAN}

Berdasarkan hasil observasi terhadap aktivitas peserta didik dalam pelaksanaan pembelajaran melalui model make a match pada siklus I pokok materi pecahan dengan ratarata sebeasr 3,15 termasuk dalam kategori baik..

Dari hasil tes materi pecahan yang dilaksanaka pada siklus I, diperoleh nilai rata-rata sebesar 79,02\% dan presentasi ketuntasan klasikal sebesar 81,08\% Dengan demikian ketuntasan klasikal masih perlu ditingkatkan. Di bawah ini adalah table prestasi belajar peserta didik siklus I.

Tabel 1. Data Hasil Ulangan Formatif Pecahan Pada Pra Siklus dan Siklus I

\begin{tabular}{ccc}
\hline $\begin{array}{c}\text { Hasil Belajar Peserta } \\
\text { didik }\end{array}$ & Pra Siklus & Siklus I \\
\hline Nilai tertinggi & 80 & 100 \\
Nilai terhendah & 50 & 70 \\
Rata-rata & 66,72 & 79,02 \\
Peserta didik tuntas & 15 Peserta didik & 30 Peserta didik \\
& $(40,54 \%)$ & $(81,08 \%)$ \\
Peserta didik belum & 22 Peserta didik & 11Peserta didik \\
tuntas & $(59,46 \%)$ & $(29,72 \%)$ \\
\hline
\end{tabular}

Berdasarkan tabel di atas, dapat dijelaskan bahwa ada peningkatan ketuntasan belajar peserta didik pada setiap siklus. Pada pra siklus, peserta didik yang tuntas baru mencapai $40,54 \%$ dan yang belum tuntas $59,46 \%$. Pada siklus I yang tuntas mencapai $81,08 \%$ yang berarti mengalamai peningkatan sebesar $39,54 \%$. Sedangkan yang belum tuntas pada pra siklus sebesar $59,46 \%$, atau mengalami penurunan sebesar $29,74 \%$. Dengan demikian aktivitas peserta didik pada siklus I masih perlu ditingkatkan.Setelah melakukan refleksi hasil tindakan pada siklus I peneliti berkesimpulan bawha penelitian tindakan kelas ini hasilnya masih kurang maka perlu di teruskan pada siklus II. 


\section{Siklus II}

Berdasarkan hasil pengamatan terhadap aktivitas peserta didik dalam pelaksanaan pembelajaran melalui model pembelajaran make a match pada siklus II pada pokok bahasan mengetahui pecahan dengan persentase 3,7 \% termasuk dalam kategori sangat baik.

Dari hasil tes materi pecahan yang dilaksanaka pada siklus II, diperoleh nilai rata-rata sebesar 94,59\%. Di bawah ini adalah tabel prestasi belajar peserta didik siklus II.

Tabel 2. Data Hasil Ulangan Formatif Pecahan Pada Pra Siklus, Siklus I dan Siklus II

\begin{tabular}{llll}
\hline $\begin{array}{l}\text { Hasil Belajar Peserta } \\
\text { didik }\end{array}$ & Pra Siklus & Siklus I & Siklus II \\
\hline $\begin{array}{l}\text { Nilai tertinggi } \\
\text { Nilai terhendah }\end{array}$ & 80 & 100 & 100 \\
Rata-rata & 50 & 70 & 70 \\
Peserta didik tuntas & 66,72 & 79,02 & 90,32 \\
& 15 Peserta didik & 26 Peserta didik & 35 Peserta didik \\
Peserta didik belum & $(40,54)$ & $(81,08)$ & $(94,59 \%)$ \\
tuntas & $\begin{array}{l}\text { (5) Peserta didik } \\
(59,46 \%)\end{array}$ & $\begin{array}{l}11 \text { Peserta didik } \\
(29,72 \%)\end{array}$ & 2 Peserta didik \\
\hline
\end{tabular}

Berdasarkan data tabel di atas, dapat dijelaskan bahwa ada peningkatan ketuntasan belajar peserta didik pada setiap siklus. Pada siklus I,Peserta didik yang tuntas baru $81,08 \%$ yang belum tuntas $29,72 \%$. Pada siklus II peserta didik yang tuntas mencapai $94,59 \%$ yang berarti mengalami kenaikan yang signifikan yakni sebesar 13,51\%. Sedangkan yang belum tuntas pada siklus II ini adalah sebesar $5,40 \%$ atau mengalami penurunan sebesar $24,32 \%$.

Rekapitulasi niai tes formatif pada materi pecahan Peserta didik model pembelajaran make a match di kelas V SDN Dawuhan 03 Kecamatan Sirampog Kabupaten Brebes dapat dilihat dalam table berikut :

Tabel 3. Prestasi Peserta Didik SD Negeri Dawuhan 03 Pada Materi Pecahan

\begin{tabular}{llll}
\hline Pencapaian & \multicolumn{2}{l}{ Siklus } & Keterangan \\
\cline { 2 - 3 } & I & II & \\
\hline Nilai tertinggi & 100 & 100 & Tetap \\
Nilai terrendah & 70 & 70 & Tetap \\
Nilai KKM & 72 & 72 & - \\
Yang tuntas KKM & 26 & 35 & Meningkat \\
Yang belum tuntas KKM & 11 & 2 & Menurun \\
Ketuntasan klasikal & $81,08 \%$ & $94,59 \%$ & Meningkat \\
Rata-rata kelas & 79,02 & 90,32 & Meningkat \\
\hline
\end{tabular}

Hasil tes belajar materi pecahan peserta didik dapat dilihat bahwa nilai materi pecahan pada setiap siklusnya mengalami peningkatan dari rata-rata 79,02 dengan kriteria baik pada siklus pertama menjadi 90,32 dengan kriteria sangat baik pada siklus kedua. Ketuntasan klasikal pada siklus I hanya $81,08 \%$ dikarenakan jumlah Peserta didik yang belum tuntas KKM masih ada dan peserta didik yang baru mengalami tes dengan model pembelajaran make a match. Tetapi pada siklus II mengalami kenaikan, jumlah peserta didik yang lulus KKM lebih banyak dari pada siklus I sehingga presentase ketuntasan menjadi 94,59\%.

Dengan demikian prestasi belajar peserta didik mengalami peningkatan dari siklus I sampai siklus II. Walaupun masih ada peserta didik yang belum tuntas sebab Peserta didik tersebut memiliki kemampuan berfikir yang berada di bawah rata-rata. 


\section{SIMPULAN}

Penerapan model pembelajaran make a match dapat meningkatkan prestasi belajar Peserta didik kelas V SD Negeri Dawuhan 03 pada mupel matematika materi pecahan. Yaitu dari rata-rata 79,02 dengan kriteria baik pada siklus I, menjadi 94,59 dengan kriteria sangat baik pada siklus II. Terdapat perubahan perilaku yang menyertai peningkatan prestasi belajar peserta didik materi pecahan setelah penerapan model pembelajaran make a match pada peserta didik kelas V SD Negeri Dawuhan 03. Mulai dari kriteria baik menjadi sangat baik.

Berdasarkan kesimpulan tersebut, ada beberapa hal yang harus dilakukan untuk meningkatkan mutu pembelajaran, antara lain dalam proses belajar mengajar tidak semua peserta didik dapat memahami pembelajaran matematika dengan baik. Oleh karena itu, guru harus memberikan bimbingan,motivasi,penjelalasn dan dapat membangun interaksi antar peserta didik dengan peserta didik maupun peserta didik dengan guru.

\section{DAFTAR PUSTAKA}

Arikunto,Suhardjono,dan,Supardi. (2010). Penelitian Tindakan Kelas. Jakarta:Sinar Grafika Offset.

Nana,Susjana.(2002). Dasar-dasar Proses Belajar Mengajar.Bandung:Sinar Baru Algensindo Rusman, (2011). Model-model Pembelajaran.Jakarta:PT Raja Grafindo Persada.

Lorna Curran. 1994. Metode Pembelajaran Make a Match. Jakarta: Pustaka Belajar

Anita Lie. 2008. Cooperative Learning: Mempraktikakan Cooperative Learning Diruang-Ruang Kelas. Jakarta: Grasindo.

https://www.slideshare.net/Interest_Matematika_2011/ajeng-nurbaiti-ulfah-0903677-1 